\title{
Representations of Zainichi Koreans in Japanese Media: The Case of The Japan Times 2000-2014
}

\begin{abstract}
Zainichi Koreans are Korean nationals, permanently living in Japan without holding Japanese citizenship. Their living conditions there have been difficult from the very beginning, dating back to 1910 . Since then, various myths and stereotypes were created about Zainichi Koreans. What is more interesting, media has been playing an important role in spreading information about them and creating a specific image about this ethnic minority in Japan. In order to find out what image of Zainichi Koreans is being created nowadays, articles in Japanese internet news website The Japan Times were used while accomplishing a discourse analysis.

Santrauka: 'Zainichi' [sk. dzainiči] korèjiečiai yra Pietų arba Šiaurès Korèjos piliečiai, gyvenantys Japonijoje nuolatinių rezidentų teisėmis. Šis statusas jiems dažnai kelia įvairių sunkumų. Žiūrint iš istorinès perspektyvos, Zainichi korèjiečiai susiduria su sunkumais nuo pat jų migracijos i japoniją pradžios, nuo 1910 m. Nuo tada apie Zainichi korèjiečius buvo kuriami įvairūs mitai, vadovaujamasi stereotipais bei išankstine (neretai klaidinga) nuomone. Nuo tada, kai žiniasklaida tapo visuotinai prieinama bei populiari, jos vaidmuo ¡vaizdžių kūrime tapo vienu svarbiausiu. XX a. antroje pusėje buvo pradèta vengti tautinių mažumu tematikos Japonijos spaudoje, tačiau pastaruoju metu ši tendencija nyksta. Šiame straipsnyje nagrinejjami dabartinèje Japonijos žiniasklaidoje pateikiami Zainichi korẻjiečių jivaizdžiai, jų pateikimo ypatybės bei tendencijos.
\end{abstract}

Keywords: Zainichi Koreans, media analysis, images.

\section{Introduction}

Traditional or paper version of media is prevailing in Japan. Nevertheless, electronic versions of newspapers are steadily being moved to websites which means better possibilities for them to be reached by the audience in all over the world. This tendency is global. Therefore the information, no matter where and for what purpose it was created, is available world-wide. This feature is important because once local, information about various issues now can be instantly acquired at any place using internet connection. 
Taking Japan into consideration, newspapers have been moving to the Internet space since 1995. By 1997 there were already 9 leading Japanese newspapers with their own online websites, including Asahi Shimbun, Yomiuri Shimbun and Mainichi (Cooper-Chen 1997, p. 67-68). Although publishing articles in English is not mandatory, some of online newspaper versions do it and some of them do it only in English, like The Japan Times. Nevertheless, use of English in Japanese newspapers is a matter of discussions. It is undisputed fact that learning a second language apart from Japanese is still not popular and teaching foreign languages in schools is a difficult task to carry out. Proponents of use of English in Japan argue that it would help to cope with globalization whereas opponents equate English to imperialism and fear losing Japanese culture by using English more often (Yoshino 2002, p. 135-136). Nevertheless, abovementioned exceptionally English newspaper The Japan Times (online version available) is targeted to a very specific circle of readers - foreign diplomatic corps, employees of foreign companies and other foreign residents and tourists as well as Japanese businesspeople, government employees and students (Cooper-Chen 1997, p. 55). In this case, use of English is fully understandable. But on the other hand, the audience itself creates a demand for specific news containing local, national, regional and international information. At the same time, the readers of English-written newspapers are living in Japan and are constantly witnessing particular events thus unpublished daily topicalities could be easily spotted. Therefore, Englishwritten newspapers in Japan should be treated as untrustworthy and unreliable sources of information from Japan for non-Japanese speakers and readers.

Putting everything into account, English newspapers which are published online regarding Japanese matters by Japanese journalists are fully eligible to use in order to become acquainted with present situation in Japan. Therefore, such internet news websites can be used not only by ordinary readers, but by researchers as well. Using contemporary research methods such as discourse analysis I shall analyse the representation of Korean residents in Japan (also known as Zainichi Koreans) in Japanese media. This topic was derived from the problem whether the ethnic minorities in Japan are represented from official (minorities do not undergo any difficulties in Japan), or from critical perspective (minorities in Japan are discriminated and this is an issue)? Here, official perspective is opposed to the critical one because from the legal point of view, non-Japanese nationals cannot be equalled to Japanese citizens, regardless the duration of their stay in Japan. "Aliens", as non-Japanese are usually referred to have been ignored by mass media in Japan for a long time in order to escape any possible misunderstandings - this will be explained later in the article. Therefore, following the official course, there should be no issues depicted in mass media regarding the ethnic minorities. Official course also encompasses interpretations of historical events and other ambiguous matters related to international relations. On the other hand, there are these 
who do not follow the official course and call themselves "independent media". Seemingly, they are not obliged to depict the situation relying on the approved governmental stance. What image is being created in the independent media about ethnic Koreans in Japan - this is the aim of the article.

The reason why the images of Zainichi Koreans were chosen as the object of the research lies beneath the origin of the phenomenon of Zainichi Koreans. Technically speaking, Zainichi Koreans is a particular socio-political construct. Its beginning may be dated back to early $20^{\text {th }}$ century, when in 1910 Korean Empire was annexed (or occupied, according to Korean stance) by Japan. More developed and industrialized Japan attracted Korean immigrants for higher wages. Later, during the WWII voluntary migration was replaced by coercive one. By the end of the war, about 1,5 million ethnic Koreans were reported to live in Japan. After the WWII the larger part of former Korean community in Japan returned to Korean peninsula, and only about 600000 of them chose to stay in Japan. After the dissolution of war-time Japan's Empire, former non-ethnic Japanese citizens lost Japanese citizenship. Among them, there were these 600000 Koreans in Japan (Kashiwazaki 2000, p. 20). Inability (till 1965 Japan had no diplomatic relations with South Korea) and reluctance (because of nationalistic attitude) to acquire Japanese citizenship created a particular phenomenon - permanent aliens in Japan - Zainichi Koreans. In other words, they are Korean nationals, permanently living in Japan, but not holding Japanese citizenship. Such dualism is causing some issues, mostly because of presumably rooted discontent against foreigners among Japanese. Although modern Zainichi Koreans are already of third and succeeding generation (phenotypically indistinguishable from native Japanese), they are still undergoing some discrimination based on their origin.

Now, Zainichi Koreans are the biggest ethnic minority in Japan (The World Factbook 2015) and tend to seemingly dominate in media headlines compared to other ethnic minorities. To unveil the images of Zainichi Koreans in Japanese media, the internet version of abovementioned newspaper The Japan Times was used. Articles were collected from the period of year 2000-2014. The paper consists of three parts: the first one is dedicated to representations of Zainichi from a historical perspective; second part is for the analysis of Zainichi representation in news website "The Japan Times"; lastly, the main points of the research are put in the conclusion.

\section{Image of Zainichi Koreans from historical perspective}

The historical conditions had a great influence in creating particular image of Zainichi Koreans. It may be said that controversial attitude towards them started creating together with the migration which started after 1910. Migrant Korean workers usually were poorly paid (Lie 2008, p. 5); their jobs were 
more dangerous than the Japanese ones. Because the migration was relatively intense, Koreans in Japan tended to live in big communities, forming separate districts in cities. These districts usually were built near factories, not far from their workplaces. Eventually, these make-shift shelters turned into relatively big, easily distinguishable Korea towns. The first Korean ghetto, a predecessor of Koreatowns, appeared in early 1900s in Osaka, Ikaino (Lie 2008, p. 5). Presently, Ikaino in Osaka is the biggest Koreatown and Osaka has the largest Korean community in Japan (Statistics Japan, 2010). Needless to say, initially Koreatowns were the places to be avoided mostly because they were known for their unsatisfactory and insanitary conditions.

Koreans in Japan were in disadvantageous position because there was a relatively small number of other kinds of Korean migrants, for example, students. Some statistics unveil that only about $10 \%$ of Koreans were in Tokyo for educational purposes in that time (Lie 2008, p. 6). The proportion was outweighed by farmers (Lie 2008, p. 4-5). This allowed Japanese majority to perceive Koreans as „lower class“ and uneducated people (and, in fact, majority of immigrants were illiterate and uneducated), eligible only for physical, dirty and dangerous work which was predominantly construction and coal mining (Lie 2008, p. 5). Supposedly because of these factors the tragic aftermath of Great Kanto Earthquake in 1923 occurred. It was one of the first and worst examples of xenophobia that was ever demonstrated against foreigners. Earthquake itself cost a massive loss of human lives but the casualties were blamed on Koreans, because it was said that Koreans poisoned the water in the wells (Lee 2000, p. 149). This rumour encouraged a rage of local Japanese and their attacks resulted in killing of several thousand Koreans simply in the streets. All in all, the image of ethnic Koreans in Japan was negative from the very beginning.

After the WWII the situation changed a bit. Nevertheless, this change cannot be classified as positive. The pre-war prejudice of Koreans remained and was supported by the general association of Koreans with criminality, illegality, violence and insolence in early after-war period (Lie 2008, p. 147). Also, Koreans were seen as greatly contributing to criminal life of Japan (Lie 2008, p. 147). Unchanging image of Koreans in Japan in immediate post-war years consisted of epithets like "dirty, low level of culture, sly, not useful for the economy, make fun of Japanese, not good for Japan, bear grudge against Japan, ugly"; in late 1970s Koreans were depicted as "sly, rustic, poor, pathetic, barbaric" (Lie 2008, p. 147).

Of course, great deal in formation of such stereotype lies upon activity of mass media, especially in later years of $20^{\text {th }}$ century. Mostly evident were the cases of failed repatriation project and Komatsugawa Incident (Lie 2008, p. 150). Nevertheless, the ignorance and oblivion were the mostly used strategies towards minorities in Japan, not excluding Zainichi Koreans. This evolved from fear of denunciation which was a consequence of the usage of derogatory 
and pejorative language towards minorities. At first, denunciation as a method was adopted by Buraku Liberation League - a political organization defending Burakumin. But apart from positive outcome - limitation of creating negative images - there were also negative consequences - self-limitation, self-censorship of Japanese media and general avoidance of issues concerning minorities in Japan (Iwabuchi 2001, p. 57). Silence and avoidance from providing the viewers with correctives was exceptionally convenient strategy for Japan government in order to obliterate its colonial past (Iwabuchi 2001, p. 57).

Image of Koreans in Japan is tightly connected to interstate relations among Japan, South and North Koreas. These relations have always been tense and the degree of tension tends to vary with the time. As it has already been mentioned, till 1965 there were no diplomatic relations between Japan and South Korea. Till now, diplomatic relations between Japan and North Korea are not established at all - just like between both Koreas. Even after the establishment of diplomatic relations between Japan and South Korea in 1965, the situation did not change dramatically - historical grievances for "comfort women" and occupation did remain, just as the unresolved territorial issues over Takeshima/Dokdo islands. Japanese media sees territorial issues as important factors, too - "[demonstrations] Fueled by the territorial dispute over some outcroppings in the Sea of Japan" (Osumi 2014). All together, these issues are still dominant topics concerning Japan and South Korea relations.

As long as Japan-North Korea relations are concerned, situation is a bit different. Having no diplomatic relations established does not prevent from various issues. There is one example - the abduction of Japanese citizens for the Japanese language teaching purposes in North Korea. This fact saw the daylight after North Korean government admitted it officially in 2002. It worsened the situation of pro-North Koreans in Japan, even though their image was already not positive due to their strong nationalism.

Altogether, these international issues tend to be re-escalated in media. The reasons may be different: issuance of new history book for schools, annual visits to Yasukuni shrine by Japanese officials, visiting disputed islands by South Korean leaders or even military activity of North Korea. Recently, most attention was drawn by Korean schools in Japan and public hate speeches, which were not managed properly by the respective institutions.

\section{Research}

Representation of Zainichi Koreans in Japanese media is a typical example of global spread of information. Zainichi is exclusively Japanese phenomenon, But internet and widespread use of the English language made the information about it globally accessible. 
There are several reasons why The Japan Times was chosen as a source of information. Main reason for that is the popularity of this online newspaper. The news in this website cover a majority of global topics, as well as a wide variety of domestic ones. The Japan Times brags itself as "most widely read English-language newspaper in Japan". What is more, it is the use of English language in the articles that makes it globally read and understood. Once the global audience is reached, the media may be used to start creating a particular image of the represented country and its citizens. Third reason is the objectivity. The Japan Times states that it is "the country's only independent English-language newspaper" (The Japan Times) ${ }^{2}$, Implying that it is a source of impartial information. It is also one of the most frequently used sources for the research on Japanese media. Also, it is one of most frequently used sources to do research on Japanese media.

Nevertheless, some controversies do remain. Since it is published in English, The Japan Times is targeted at the global rather than domestic audience. Because of this, it can be said that the news in The Japan Times can be misleading at some point. Staff writers are not only Japanese nationals and there is a possibility that they can provide attitude which is different from Japanese one - just only because they write to nonJapanese readers. But at this point the risk becomes unavoidable. This is why discourse analysis is used to find out about the Zainichi Koreans representation in Japanese media.

\section{Methodology}

For this research, discourse analysis methodology was used. It is a widely used tool and the most suitable for qualitative media analysis. Subjectivity in qualitative analysis is usually difficult to avoid, therefore it should be kept in mind that the evaluations in this paper are valid as long as they are perceived in the given context. Changing the context simultaneously changes the evaluations and the alternate results would be legitimate as well.

Discourse analysis has a great variety of different evaluation parameters and frameworks based on those parameters. But there are few of them, usually referred as core evaluative parameters - comprehensibility, emotivity, expectedness, importance, possibility/necessity, and reliability (Bednarek 2006, p. 45). For this particular research, the most important parameter is emotivity. This parameter is concerned with the writer's evaluation of aspects of events as good or bad (Bednarek 2006, p. 74). It is said to be the most problematic, because emotive meaning is not easily objectively verifiable or recognizable and its analysis is often highly subjective, even more than that of evaluative meaning in general (Bednarek 2006, p. 46). But apart from it, emotivity can be considered as basically the main tool while creating an image of a 
particular issue, therefore the analysis of the media corpora here was done mostly according to this parameter.

\section{Sources of research}

The relevant information for the research was collected from The Japan Times website using preinstalled the search tools. The term "Zainichi" is usually avoided in the media and a more politically correct term "Koreans in Japan" is used instead. Therefore, the term "Korean" was chosen as the keyword for the search. Thus the search results included all "Zainichi" related articles in which they are explained as "Ethnic Koreans in Japan", "Koreans in Japan", "permanent residents in Japan" and similar. The search tool has disadvantages as well, because search by keyword "Korean" provided results for "Korea" (South and North), "Korean" (citizen of South or North Korea, not a permanent resident in Japan). Therefore, in order to carry out this analysis the whole content of the articles was taken into consideration. All in all, 46 articles were collected as proper, dating from April 30, 2000 to July $222014^{3}$.

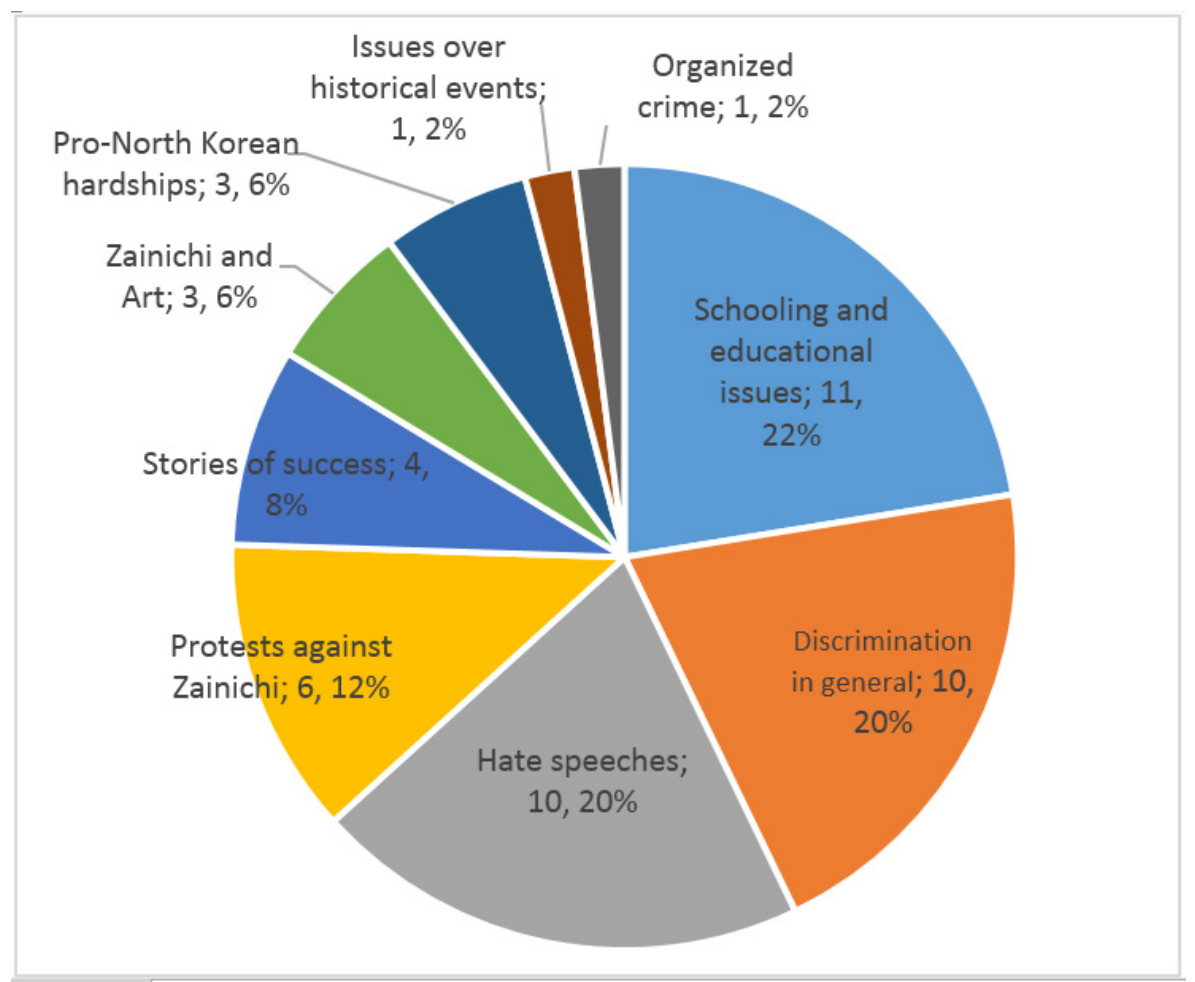

Diagram No. 1. Topics and their popularity 
There may be distinguished few types of articles, which write about Zainichi Koreans. First of all, there are plain messages, reporting a particular piece of news. Usually they are short and use formal language. The second and most popular type is comprised of articles from the printed version of the newspaper. It may be an article by a staff writer, editorial article or a compilation from other news agencies. Third type is an interview. There are few of them, but they provide some valuable information as long as the interviewees are directly connected to the Zainichi Koreans. Lastly, there are articles, written by the readers of the newspaper. These comments vary in terms of extent, but the language used there is usually informal and emotional. Which makes it useful, because it comes directly from the masses.

Relatively the largest part of articles comes from 2013 (18) and 2014 (8). It should be kept in mind that it was a middle of the year 2014 when the research was conducted thus there is a possibility that year 2014 eventually may have more relevant articles than year 2013. In 2012 there were no relevant articles found, in $2011-1$, in $2010-4$, in $2009-0$, in $2008-2$, in $2007-5$, in 2006-2003 - 6, in 2000/1 - 3 articles (see Diagram No. 1). Such a distribution of articles may be explained differently. Mainly, the Zainichi Koreans may have become more noticeable during the last year because issues related to them supposedly became more important or these issues have become more interesting for the media itself. But the absence of relevant results in year 2012 remains unknown. Therefore, it may be said that in this case representation of Zainichi Koreans can be split into two main periods - before 2013 and after 2013. Secondly, this distribution of articles may be arranged by the search engine of the website itself, although the search results were set to be shown both by relevance and by date, carrying out the search twice. Nevertheless, the fact that from the time span of 14 years, which were taken into consideration, more than half of articles were written during last 14 months clearly shows that dogma of ignorance and avoidance of topics concerning minorities' issues are being constantly abolished from mass media.

As it may be seen from the Diagram No. 2, years 2013 and 2014 are exceptional not only in terms of number of articles but in terms of variety of the topics as well. Looking more closely at the topics of recently published articles, there may be seen some dominant ones, for example hate speeches (10 instances), public protests against Zainichi Koreans (4 articles), schooling and education issues ( 6 articles), 3 articles about Zainichi related stories of success, 2 articles related to discrimination and one article about hardships of pro-North Korea Zainichi. As long as earlier published articles are concerned (2000-2011), main topics are as follows: discrimination in general (8 articles), schooling and education issues (5), Zainichi Koreans represented in art , such as movies and books ( 3 instances), pro-North Zainichi Koreans' hardships (2 articles), issues over historical events (1), Zainichi and organized crime 


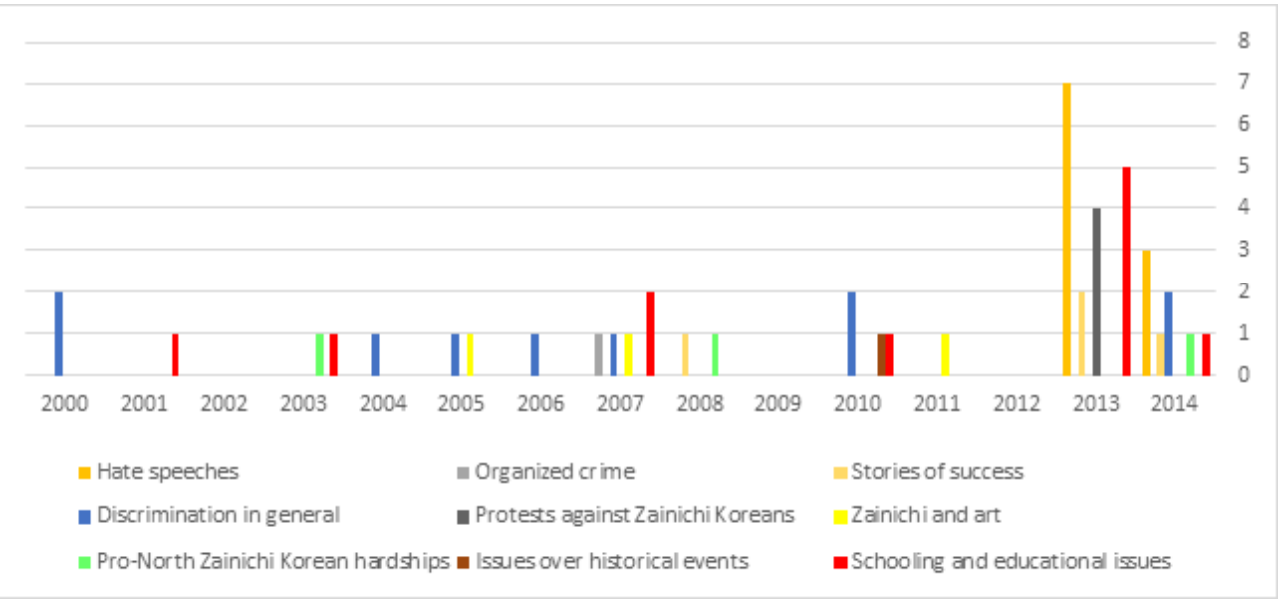

Diagram No. 2. Topics and their appearance.

(1). Comparing the topics between the two different periods, it may be seen that discrimination in general later was replaced by hate speeches; schooling and educational issues remained during all the period; protests against Zainichi Koreans till 2013 were not escalated, while the hardships of being pro-North Zainichi Korean were mentioned only few times until 2014. By saying "hardships" I infer schooling and educational issues, because only the Chongryun (pro-North Korean Zainichi organization) is having problems with their schools, but just for the matter of clearness, a separate group is being created.

The categories have been named after the main topics of the articles. The largest part of articles fall in three categories: "Schooling and educational issues", "Discrimination in general" and "Hate speeches" having 11, 10 and 10 articles respectively. This means that these groups constitute roughly two thirds of all articles leaving other 6 categories to share about $1 / 3$ of all the rest of articles.

\section{Schooling and educational issues}

Articles in category "Schooling and educational issues" are predominantly dedicated to pro-North Korean Zainichi related issues. In earlier period, till 2013, schooling issues were among the dominant ones. Earliest found article on this issue was published in 2001. It seems like it was the first article ever dedicated to schooling issues because the whole situation in both Mindan and Chongryun schools are described in a detailed manner, especially regarding history classes. The article mainly focuses on the differences between Japanese 
and Korean style of teaching this subject. Such expression like "remarkably different view of $20^{\text {th }}$ century history" (Johnston 2001), shows a different nature of education and formation of attitude towards the past events, therefore towards the influence of these events to the modern world. What is more important, history of the $20^{\text {th }}$ century is being taught more elaborately than other historical epochs with illustrations showing "forced laborers hauling goods under the eyes of watchful Japanese" (Johnston 2001). Such vivid descriptions infer intentions to depict Korean schools and their students as being not prepared to cope with Japanese demands in terms of education, not to mention narrow-mindedness of their graduates. Nevertheless, in the end of the article there is a statement claiming that students "just want to know if they are going to have to know the material for a test or university entrance exam" (Johnston 2001). By doing so, author seems to vindicate the students virtually putting all the fault on the officers who are responsible for the curricula.

Another article on schooling problems among Zainichi Koreans was published in 2003, when the issue of abductions was a prevailing topic in media. For instance, the article under the title " Daiken' a discrimination snafu" (Arita 2003) is dealing with 'daiken', qualifying test for non-Japanese schools' graduates willing to enter Japanese universities. This article is explaining Japanese government's anti-Pyongyang position towards Korean schools in Japan that are predominantly run by Chongryun organization, which is known for its relations with North Korea. Students of such schools are shown as discriminated because Japanese government is depicted as not acting according to United Nations regulations which were ratified by the government itself earlier.

Nevertheless, there are even articles which represent the situation of Zainichi Koreans from unexpectedly positive perspective. Article under the title "Seeing from the Korean side" by Jason Williams, a teacher at Korean pro-Pyongyang school, depicts Zainichi students as victims of prejudice, especially after the abductees issue was brought to publicity. One of the main reasons, why the prejudice is so prevailing, is said to be the lack of attention from the media. Interesting fact is that the author cites a complaining school representative who is saying that right-wing activists are constantly doing damage to Korean schools but society is not informed about that (Williams 2007a). For the sake of truth it has to be said that year 2007 is not exceptional in terms of active representation of anti-Korean activities (refer to Diagram No. 1) although it is said that there were more than 150 various incidents concerning Zainichi Koreans (Williams 2007a). By writing this article, J. Williams tried to represent Korean residents in Japan as disadvantaged, prejudiced and being victims of fierce opposition. What is more important, he exposed media as passive and seemingly intentionally omitting the issues related to minorities in general and Zainichi Koreans in particular. 
Another article by the same author is titled "Koreans speak out on schooling". Similar in content but different in its form, this article also focuses on disadvantaged position of Chongryun-related schools and their students. In this interview-like article author uses some noteworthy expressions like "establish my pride as a Korean", "Korean in the true sense" (Williams $2007 \mathrm{~b}$ ) and it indirectly implies that pro-North Korea Zainichi are willing to remain in their own relatively closed community fostering their culture and language although diplomas from Korean schools in Japan are not accepted as legal documents to prove one's education.

Few years later schooling issue was once more escalated while talking about Chongryun schools and plans to omit them from a planned tuition-free program (The Japan Times 2010c). As a rule, this issue is not connected to Mindan schools but once again, the rhetoric used does not differ a lot - article contains topics like "political and diplomatic reasons", "violation of human rights", "ethnic discrimination" (The Japan Times 2010c).

In 2013 the schooling issue appeared one more time, but in much greater extent. In 2013-2014 there were 6 articles dedicated to this issue compared to 5 articles that were published in 2001-2012. This is mainly because of Korean schools that have been excluded from abovementioned tuition waiver program. More particularly, a Chongryun school in Kitakyushu has also been excluded and due to that local Zainichi Koreans have filed a damages suit from the government for the discrimination (The Japan Times 2013a). In another publication it is mentioned, that "the nuclear issue with North Korea and the past abductions of Japanese citizens are cited as the pretext" (Kimura 2013). Use of word "pretext" shows that the tuition waiver is justified by external reasons, which could not be treated as sufficient in other context. Also, this example shows the influence of bilateral issues to life of Zainichi Koreans.

The repeating of the tuition waiver issue in the media allows us to perceive the situation more precisely, because the repeated information creates an image of resonant issue. Consequently, every new publication adds some additional details about the discussed problem. The article under the title "Targeting ethnic high schools" is a reader letter, thus it may include subjective information, but the article is started by the bare fact, that "On March $31^{\text {st }}$ about 6,000 people attended a meeting in Tokyo to demand that Korean high schools remain eligible for free tuition" (Kimura 2013). It does not clarify whether the people who gathered there were Zainichi Koreans or their supporters. Nevertheless, the number of the protesters imply that this issue has crossed the boundaries of Kitakyushu and has become a matter of wider audience.

Similar rhetoric is being used in the article "Students convenient proxies in LDP's Pyongyang angst" by Phillip Brasor. Author states that the issue of abductees, North Korea's nuclear disarmament, armed clashes between South and North Korea (sic!) have been effectively used to stop the progress of curricula of Zainichi schools (Brasor 2013); consequently, schools were 
excluded from tuition waiver program. Of course, Zainichi Koreans are depicted from a compassionate perspective. It is said that officials hold "antipathy" towards them and want "to make them feel bad about something they have no control over" (Brasor 2013). Author claims that government's position towards Zainichi Koreans is based on "hearsay and conjecture" and that "even if the Chongryon schools do instil the Kim Jong Un doctrine in students there is nothing illegal about it" (Brasor 2013). Doing so, author virtually vindicates students and puts the pressure on Japanese government for its decisions and position.

The most recent article on this issue takes a different step and speaks about pro-South Korea school in Osaka. The trends have been that pro-North Korean schools were to be retrieved from their negative image in the society. This time the situation is opposite because pro-North Korean educational institutions are represented as spreading propaganda, showing "footage in class that emphasized the prosperity of North Korean society" (Eto 2014). Also, both pro-South and pro-North Korean schools are said to be imitating "that of the "home" country — that is, North or South Korea, depending on the school's affiliation" (Eto 2014). Therefore, new type of school, meeting the standards of Japanese educational system, was introduced to Zainichi Koreans. Nevertheless, it still has close ties with South Korean educational institutions thus it cannot be said that this new type of school is not independent from a particular country. The article eventually tries to convince that pro-South Korea schools are looking forward to improving their curricula, continuing the progress and meeting the needs of modern Zainichi society.

To conclude, articles on schooling issues have been trying to persuade to change the readers' minds and start thinking about Zainichi Koreans' education from other than negative perspectives. Nevertheless, the most recent article (un)intentionally returns to the idea that pro-North Korea schools are keen to use propaganda. Therefore, schools of Chongryun and their students are disadvantaged compared to students of Mindan schools because of their lack of recent information and analytical skills which are not gained at Chongryun schools.

\section{Discrimination in general}

Another relatively frequent topic concerning Zainichi Koreans is discrimination in general. The articles fall into this category because they could not be assigned to more specific groups, for example, schooling or hate speech. Discrimination in general was identified by the common message, brought through an entire article. It does not necessarily has to be straightforward use of words like "discrimination", "discriminatory", "limitations for ethnic Koreans" or similar expressions and terms. 
The message sent may even be misleading at first, for example, article under the title "Isomura 'sangokujin' explanation irks Koreans" (Johnston 2000) has a subtitle "Local ethnic community miffed with mayor despite his criticism of Ishihara's gaffe" and the text itself states "Isomura, however, has not offered a further public explanation [about not sharing Ishihara's feelings] and city officials said he has no plans to do so" (Johnston 2000). While the title simply states the fact of "irked" Koreans (with no additional explanations, which Koreans), subtitle tries to justify Isomura by saying, that he actually tried to criticize Ishihara's nationalistic attitude. But the body of the text confuses the situation, eventually stating that Isomura is not going to explain, what he had meant by saying "non-inflammatory", while some media reports quoted him saying "not discriminatory" (Ishihara's statements about immigrants in Japan) (Johnston 2000). The usage of such words is extremely sensitive in Osaka, where the population of Zainichi Koreans is the biggest of all the cities in Japan. Therefore, the title, the subtitle and the article itself provide different feelings about the same issue. The ending of the article is noteworthy too, because the Korean community is described by expressions "[ethnic Koreans] descended from (...) forced laborers, following Japan's annexation of the Korean Peninsula", "Osaka area, home to Japan's largest Korean community" or "Despite the grim history, though, many ethnic Koreans say they feel more comfortable in Osaka than in other cities" (Johnston 2000). Usage of words like "home", "forced laborers" or the composition of "grim history" and "feel more comfortable" in the same sentence provides the overall emotion of being compassionate about Zainichi Koreans, their history and present situation.

Another article which is one of the earliest found on Zainichi discrimination issue is named "Osaka recalls booklet over offensive cartoon". The article is written using formal language, but while talking about Japanese alias it is said that they are used "to disguise their ethnicity for fear of discrimination" (The Japan Times 2000). Words like "disguise", "fear" and "discrimination" in one sentence create negative atmosphere which is presumably surrounding Zainichi Koreans in their everyday life according to the author of the article. Similarities are seen throughout other articles in this category - Kanako Takahara in 2005 wrote: "[Koreans in Japan] inclined to assimilate to dodge racism", "Koreans hid their ethnic background and lived under Japanese aliases to assimilate into the society or to avoid discrimination", "Koreans were forced to become Japanese citizens during the colonial rule era, they were stripped of that status after the war", The words "were forced" were used a couple of times while talking about the history of Zainichi (Takahara 2005). The article under the title "Facing eviction, Uji ghetto gets Seoul aid" is dedicated to represent legal issues of abolishing Korean ghetto in 1989. Because of article's topic, it is mainly speaking about living conditions of Zainichi Koreans and the conditions are said to be "precarious", "deplorable", 
with "poor existing basic infrastructures", and concluding that "their basic rights have been violated for over 60 years" (The Japan Times 2007). Article under the title "Koreans, Japanese demand full compensation" continues to depict Koreans as disadvantaged minority; even annexation of Korea in 1910 is called "forced", not to mention "“comfort women" who were forced to provide sex for Japanese soldiers" (The Japan Times 2010a). Discrimination in general is being discussed in the article "Yearning for multiculturalism". Along with other foreigners, Koreans in Japan are presented as discriminated not only in "bald-faced" manner, but from identity-related perspective too, for example, when "their ethnic identity isn't recognized" (The Japan Times 2010b).

Articles in this category have appeared again, in 2014. Article named "More racist stickers discovered at Shikoku pilgrimage restrooms" shortly presents anti-Korean activity by sticking discriminatory stickers in the places which are often visited by tourists. The latest article "Counseling offered for Korean youths in Japan victimized by discrimination" encompasses various Zainichi-related issues, for instance hate speeches in the Internet, protests against Zainichi Korean in public, bullying in schools (Osumi 2014).

All in all, discrimination in general is a topic that is seen throughout all the period from year 2000 till 2014 with few breaks of couple of years. Because of that, this category is second biggest among all 9 categories, but it had not exceeded 2 articles per year; usually there was only 1 article per year assigned to this group. Looking at the contents of these articles it may be said that frequency is not instigated by significant events. Therefore I presume that discrimination is a constant topic while referring to Zainichi Koreans in Japanese media.

\section{Hate speeches}

In this article, there are two similar categories defined - "Hate speeches" and "Protests against Zainichi Koreans". Speaking generally, it may be said that both categories may fall into one bigger group, because acts of hate speech and the protests are kinds of manifestation against Zainichi Koreans. Nevertheless, there are some major differences. Hate speech was first defined by United Nations International Convention on the Elimination of All Forms of Racial Discrimination in 1965. This document prohibits "all disseminations of ideas based on racial superiority or hatred, incitement to racial discrimination, as well as all acts of violence or incitement to such acts against any race or group of persons of another colour or ethnic origin, and also the provision of any assistance to racist activities, including the financing thereof" (United Nations 1971, p. 212). According to this international document and as long as the media representation is concerned, eventually two different categories 
can be distinguished. Hate speeches encompass only written or spoken language which is used to insult or to express hatred against Koreans in Japan; therefore articles about Internet (anonymous) insults undoubtedly fall into hate speech category as well. The category "Protests against Zainichi Koreans" is distinguished to encompass the articles about physical activity against Zainichi Koreans, for example, gatherings in public places or near Korean schools. Both categories are most dominant in year 2013 and 2014 when hate speech and protests against Zainichi Koreans together make 14 articles while the rest 7 categories make 11 articles in total.

Hate speech is the most recent topic regarding Zainichi Koreans. The hate speeches became observable since the beginning of year 2013, when pejorative and discriminatory rhetoric was brought not only in the internet, but in public places during anti-Korean rallies as well. Whole series of articles, dedicated to this particular issue, implies that it has acquired a considerable attention from the society. The ingenuity of provocateurs is seen in the hate language they use to describe Koreans in Japan: "cockroaches", "Kill Koreans", "throw them into the sea", "[Koreans to be] Holocausted" and other slogans (Osaki 2013). Similar rhetoric is seen in another article - "Kill both good and bad Koreans," "Koreans, get out," and "Sink them in Tokyo Bay" (The Japan Times 2013f). The article is started by saying that "demonstrations [are] repeatedly held in Tokyo's Shin-Okubo district, home for many Korean shops and restaurants" (The Japan Times 2013f) therefore author implies that the article is about a constantly occurring phenomenon, not a onetime event. I suggest paying attention to a word 'home' while talking about Shin-Okubo in this sentence. Author consciously used it instead of other terms which could be used to define a place of residence or occupation.

Article under the title "Xenophobia finds fertile soil in web anonymity" shortly presents online hate speech phenomenon. The author uses a mixture of formal and relatively emotional language, especially while talking about antiKorean activity: "Japanese (...) vent their political spleens online", "blaring sound trucks spewing nationalistic slogans", "ordinary Japanese who only fan the nationalist fires online" (Mie 2013). Similar, but less eloquent style is found in the article by Eric Johnston. Author writes about possibilities to legally prohibit hate speech against Zainichi Koreans which can be even acted by a 14-year-old girl who "using a microphone loudly maligned Korean residents, saying she despised them and warned them to relocate to the Korean Peninsula or be massacred" (Johnston 2013). Nevertheless, author did not come up with any possible ending in this situation. A continuation of this article did occur a month later. A reader's letter was published on the same topic but with more emotional language - "demonstrations (...) which demonize foreign residents", "ghoulish mobs of fanatics", "unconscionable callousness or the most obscene brand of cynicism (targeted to Shinzo Abe for not taking measures to stop hate speeches)" (The Japan Times 2013d). 
The article by Jeff Kingston appeals to Tokyo as the city of Olympic Games in 2020, opposing the present situation, full of xenophobic assaults, with peaceful ideals of Olympics. The government is to be blamed the most, even the title says that, "Abe ought to show a red card to hate speech now" (Kingston 2013) thus giving the allusion to one of most popular sports in Japan, football. But just like in football, the referee shows a card by his own consideration, Abe is shown as a metaphorical referee and he cannot be forced to do so. Therefore, what is left to do, it is only appealing to the virtues of harmonious society, but until freedom of speech is not sanctioned not much is to be expected from the government. As much as Zainichi Koreans are concerned, they are presented as "no strangers to prejudice" or the subjects of "minority scapegoating".

Basically, in the articles dedicated to hate speech against Zainichi Koreans, compassion and support is mostly felt for the hate speeches' targets. Although it is not said directly, but it is perceived as such, because of antipathy for the provocateurs. The whole setting, allowing the hate speech to happen, is described as "bigotry", "jingoism", "shamefully out of step with 21 st-century values and norms" and "tarnishing Japan's reputation" (Kingston 2013). Here is another instance when Koreans are described from perspective of compassion referring to "those who aim hate speech at Koreans and other foreign residents in Japan as bigots", later writing "ugly, threat-spewing demonstrations" (The Japan Times 2013f). Condemning language is used in another article from this category, "Court bans rightists' hate speech, rallies". The article is from a series on the acts of hatred against Zainichi Koreans. While retelling the background of the present situation, author states that "[Zainichi Koreans are] descendants of forced laborers shipped to Japan during its brutal 1910-1945 colonial rule of the Korean Peninsula" (The Japan Times 2013b).

Nevertheless, there are articles with plain information about Zainichi Koreans and their situation in Japan. One of them is a message-type article "U.S. human rights report cites anti-Korean hate speech in Japan". Text is formal but Zainichi Koreans were still represented as discriminated and that Zaitokukai "used racially pejorative" during their demonstrations (The Japan Times 2014a). The same type of article is "Japanese high court upholds ruling against anti-Korean activists' hate speech" which continues to present an ongoing dispute between Zaitokukai and the authorities of one Korean school upon anti-Korean protests in front of that school. Although the text is formal, Zainichi Koreans are represented in the context of negative events (The Japan Times 2014b). The latest article in this category is dedicated to a new form of Zainichi-related issues - anti-anti-Korean movement which is focusing its activities against Zaitokukai (The Japan Times 2014c). Just like the two earlier mentioned articles, this one too has a formal form and a negative background in which Zainichi Koreans are depicted. As much as the aim of this research is concerned, these findings are valuable and they 
show that representation of Zainichi Koreans in Japanese media is usually implementing negative aspects.

\section{Protests against Zainichi Koreans}

Articles of three categories: "Schooling and educational issues", "Hate speeches" and "Protests against Zainichi Koreans" constitute the absolute majority of articles dedicated to Zainichi Koreans, published in 2013. Nevertheless, only articles for hate speech and protests are related in context. Articles, dealing with schooling issues, are dedicated to tuition waiver exclusion which did not ignite anti-Korean rallies or hate speech instances. All in all, there are 5 articles that I have classified as dealing with protests against Zainichi Koreans.

According to the articles, there are few forms of protests. Most popular are two: gathering in front of Zainichi Korean buildings (i.e. schools) and massive demonstrations in the streets. In the beginning of the article it is said that it was a "410 demonstration" (The Japan Times 2013c). Such a preamble implies that demonstrations of this kind is nothing new and the community might be even used to it. Usually such demonstrations are peaceful in terms of not turning into riot, but this particular occasion contained an act of brutality, although it is not clarified, who was attacked. Just like the earlier example, the location of Zainichi Koreans is called "home" therefore protesters are depicted as intruders or uninvited "guests" to the "home" of Koreans. Another example of demonstrations is represented in the article under the title "Rallies dent business in Koreatown" (Sato, 2013). It speaks about massive demonstrations (more than 500 people) have clashed in the streets of Koreatown, which is recently undergoing a decline in business because of constant protests. It is said, that the protests have become more frequent after South Korean President Lee Myung-bak visited Dokdo/Takeshima islands. "Tokyo-Seoul ties toxic as Biden visits to push reconciliation" mainly focuses on analysing bilateral relations between South Korea and Japan but Zainichi Koreans are not left behind. In this article Koreans are shortly mentioned in the context of anti-Korean rallies.

There are articles which may be assigned to both groups, hate speeches and protests, while presenting large-scale demonstrations. The author of one of them, Chico Harlan, adds some examples of hate speech, too - "go home or die", "[we will] flatten this neighborhood", "hang yourselves" (Harlan 2013). Nevertheless, the ending of the article talks about pro-Korean groups, less organized than Zaitokukai but acting publicly during anti-Korean demonstrations thus creating an opposition for them. This aspect is important because although the context of the article remains the same - Zainichi Koreans are discriminated and not defended by law - but there is a growing conscience in the society 
which tries to fix the situation. What is interesting here, such pro-Korean activities are said to be not represented by South Korean media although anti-Korean rallies are covered relatively well (Harlan 2013).

To conclude, it should be said that assigning articles to a particular category is a relative action. Especially it is evident in this case when hate speech and protests are extremely related. While hate speech can occur without public demonstration, it is difficult to imagine public demonstration without hate speech during it. But only because physical presence of anti-Korean activists does not necessarily mean acts of hate speech, these two separate categories are left in this classification. On the other hand, the number of articles in this category implies that public demonstrations against Zainichi Koreans is a constant issue and there are still no effective measures to deal with it. Therefore, the representation of Zainichi Koreans in the media creates an image of them as subjects of rallies against them.

\section{Stories of success, Zainichi in art}

Having analysed the major topics, there are 5 more of them left which comprise only $1 / 4$ of all the articles. Among them, only "Stories of success" and "Zainichi in art" are relatively neutral or even positive. Nevertheless, looking deeper in the texts of these two groups, the positivity can still be questioned. For example, in the article "Movie portrays struggle of ethnic Korean who became rikidozan" (The Japan Times 2005), the storytelling cannot cope without humiliating expressions cited from the movie, for example, "What I hate most is to see a smiling Korean" (The Japan Times 2005). Another important fact is the tragic end of protagonist's life because he was fatally stabbed in a brawl. Second article from this group is "Unafraid of rightist rage" (Schilling 2007). There, the movie director Kazuyuki Izutsu speaks about his new film "Pacchigi! Love \& Peace" and states: "Ethnic Koreans are still reluctant to say who they are; they worry that they might not get any more work. There's still a lot of discrimination against them" (Schilling 2007). Third example is the article under the title "Korean singer soothes strained ties" (Matsumoto 2013). The article is a typical story of success - ethnic Korean in Japan gets awarded for her contributions to deepening bilateral relations through music. Nevertheless, at the end of the article it is said, that "I have [...] shared the joy (despite strained relations)" (Matsumoto 2013). Another article from the category "Stories of success" is about the writer of Korean descent Min Jin Lee who uses fiction as a means to unveil hardships and problems of Zainichi Koreans. Min Jin Lee herself is not Zainichi Korean but she says she is aware that "the diaspora of Koreans throughout the world has led to their own communities" and that in Japan "There is an assumption that if you're ethnically Korean, you're automatically against 
Japan" (Hornyak 2008). A story of success is told in the article "Tokyo's Koreatown emerged from the flow of bilateral ties". History of Shin-Okubo is told through the perspective of Korean businessman. Nevertheless, antiKorean activities are not omitted here, because the article was published in 2013 when such rallies were becoming a usual thing in Shin-Okubo district. Eventually, this particular article represented Zainichi Koreans as people who can cope with the emerging problems and think not only about local issues, but look at the wider perspective as well. Similar attitude is being represented in article "Kobe neighborhood gets spicy with 'kimchi town' moniker" which portrays Zainichi Koreans as being able not only to deal with discrimination but advertise themselves too, by using kimchi, traditional Korean dish. It is said that Zainichi Koreans are assimilated with local Japanese therefore even kimchi tastes different to adopt it to Japanese tastes (Osaki 2014).

Zainichi Koreans in art are represented in an article "Shining a light on Korean sorrow in Japan" by Michael Hoffman. In this review, works of Zainichi Korean writers are presented mainly using negative attitudes just because the writings are from negative perspective. Expressions like "I battle (...) in the same way that Koreans battle oppression", "If those children knew I was Korean, I'm afraid their feelings for me would change", moreover, there is only one happy ending in the "bleakly pessimistic volume — the only light that isn't a lurid glow" (Hoffman 2011).

Having these examples in mind it may be said that even presumably positive topics do comprise some negative attitudes, although while reading the given information, more positive facts dominate, such as the production of film, paying the honour to legendary sportsman, the awarding of famous singer. The information is transferred in a subtle way by stating the facts of discrimination or worsened bilateral relations on the one side, but doing it only in the context of positive news.

\section{Less dominant topics}

Hardships of pro-North Zainichi Koreans, issues over historical events and organized crime are similar in context. As the labels of the categories imply, all the articles in these categories witness difficult existence of Korean residents in Japan. First of all, Zainichi from North Korea, escapees from the regime, are shown from compassionate perspective saying that their former place of residence was with "hellish life in a dictatorial state" and now they are afraid of persecution therefore they are using Japanese aliases (The Japan Times 2003). In addition, Korean community in Japan is said to be "insular", especially pro-North Koreans, and teaching pro-communist material at their schools (McBride 2008). But all this information is posted not judging Zainichi Koreans but representing them from the perspective of victims of the 
prevailing system. The same is seen in the article under the title "Group says Gunma government trying to remove memorial for Korean forced laborers". Author of the article tries to persuade the readers that initiatives to remove a memorial stone are based on the bare fact that the memorial was built by Chongryun organization - "The monument was initiated by Giichi Tsunoda, a former Upper House vice president who stepped down in 2007 after his connections with Chongryon" (The Japan Times 2014d). The maintenance of the monument was legally assigned to local government for 10 years and since the contract has expired in 2014, local authorities are not willing to renew it. Therefore, author cites Chongruyn head as saying "The government tries to eliminate ethnic education" (The Japan Times 2014d).

Category "Zainichi Koreans and issues over historical events" has only 1 article in it, "The annexation of Korea". Whole rhetoric of the article implies that the period between 1910 and 1945 was only destructive and negative. Some expressions prove this statement - "one should not forget the discrimination and sufferings that the Korean people experienced", "Korea's crops were "plundered by Japanese imperialism"”, adding a virtual provocation "Those who try to justify the annexation of Korea..." (The Japan Times 2010d). Just because the article is dedicated to the annexation of Korea, it has direct connections with Zainichi Koreans who have settled in Japan mainly during this epoch. Therefore, this article indirectly brings pro-Korean message, condemning Japan's rule of these times.

The last category is related to organized crime. Although it has been said earlier that Zainichi Koreans were related with criminal activity, only one article could be found dealing with this particular issue. This article gives a deeper insight into pachinko industry, mainly operated by pro-North Korea Zainichi. Pachinko is said to be related to North Korea and money from this industry are supposedly channelled to Pyongyang. In the article pachinko is followed by epithets "shady dealings", "grey area", sending to North Korea "about $¥ 200$ billion annually” and funding "Pyongyang’s missile programs" (Shimizu 2007). Nevertheless, this is the only instance found of bringing unclear links to public.

\section{Conclusion}

Having analysed the topics concerning Zainichi Koreans on media, certain tendencies in making the image of Zainichi may be seen. First of all, as already mentioned, the topics are almost all from negative perspective. This may be influenced by the needs of audience, because negative pieces of news are more popular and intriguing than the positive ones. Therefore discrimination, hate speeches, protests and demonstrations, restrictions in education, various grievances from the historical perspective are dominant topics while talking 
about Koreans in Japan. In the articles, Zainichi Koreans are represented as disadvantaged, repressed, discriminated ethnic minority in unwelcoming Japanese society. This is the same while talking about pro-South and proNorth Zainichi Koreans which is an interesting result, because in Japanese society pro-North Zainichi Koreans are usually perceived as more negative members even among other "negative" non-Japanese. Moreover, pro-North Zainichi Koreans are represented with more compassionate epithets than those, which are used to describe pro-South Zainichi Koreans. This may be because the articles about pro-North Korea Zainichi Koreans occupy a larger proportion than the articles about pro-South Korean ones. Another noteworthy result of the analysis is that even though the Koreans in Japan are usually depicted in a negative context, the usage of words, figures of speech and expressions create an image of Zainichi Koreans as people who have done nothing to be hated or discriminated for. This proves the premise that The Japan Times as a newspaper and its internet version can be treated as independent mass media sources and apparently not mainstream ones. In other words, Zainichi Koreans are represented from non-official perspective, although the attitude sometimes is even too compassionate and may suggest a pro-Korean perspective instead of critical one.

The number of articles per year has been varying throughout the whole period. Initially, Zainichi topics were not popular, but since 2013 articles about Koreans in Japan have been published relatively often. I presume that this growth is initiated by two factors: emerging public activity by anti-Korean groups and a diminishing tendency in media of ignoring matters which are related to minorities. Nevertheless, there are other trends too: more and more Koreans in Japan are obtaining Japanese citizenship, consequently changing their nationality. Annually, there are about 10000 of such cases and there is a possibility that in a longer run Zainichi Koreans will cease to exist because legally they will be treated as Japanese nationals. Consequently, by that time escalating the Zainichi issues will be a topic for sociologists and social historians, not journalists and media.

\section{References}

Bednarek, M., 2006. Evaluation in Media Discourse. New York, London: Continuum.

Cooper-Chen, A., 1997. Mass communication in Japan. Ames: Iowa state university press.

Iwabuchi, K., 2001. Political correctness, postcoloniality, and self-representation of "Koreanness" in Japan. In: S. Ryang, ed. Koreans in Japan. New York: Routledge, pp.55-73. 
Kashiwazaki, Ch., 2000. The politics of legal status. In: S. Ryang, ed. Koreans in Japan., New York: Routledge,. Pp. 13-30.

Lee, K., 2000. Koreans in Japan. Seoul: Jimoondang.

Lie, J., 2008. Zainichi (Koreans in Japan). Berkeley: University of California Press.

Yoshino, K., 2002. English and nationalism in Japan: the role of the interculturalcommunication industry. In: S. Wilson, ed. Nation and nationalism in Japan. New York: Routledge, pp.135-145.

About Us. In: The Japan Times. Available at: <http://www.japantimes.co.jp/aboutus/ $>$ [Accessed 21 August, 2014].

Arita, E., 2003. 'Daiken' a discrimination snafu. The Japan Times, 13 April. Available at: $<$ http://www.japantimes.co.jp/news/2003/04/12/national/daiken-a-discriminationsnafu> [Accessed 21 August, 2014].

Brasor, Ph., 2013. Students convenient proxies in LDP's Pyongyang angst. The Japan Times, 3 March. Available at: <http://www.japantimes.co.jp/news/2013/03/03/ national/media-national/students-convenient-proxies-in-ldps-pyongyang-angst/> [Accessed 21 August, 2014].

Eto, F., 2014. Osaka school offers new approach to education for ethnic Koreans. The Japan Times, 3 April. Available at: < http://www.japantimes.co.jp/news/2014/04/03/ national/osaka-school-offers-new-approach-to-education-for-ethnic-koreans/> [Accessed 21 August, 2014].

Harlan, Ch., 2013. Shin-Okubo, window on a sad regional rift. The Japan Times, 6 December. Available at: <http:/www.japantimes.co.jp/news/2013/12/06/national/ shin-okubo-window-on-a-sad-regional-rift/> [Accessed 21 August, 2014].

Hoffman, M., 2011. Shining a light on Korean sorrow in Japan. The Japan Times, 17 April. Available at: <http:/www.japantimes.co.jp/culture/2011/04/17/books/ shining-a-light-on-korean-sorrow-in-japan/> [Accessed 21 August, 2014].

Hornyak, T., 2008. Tackling the 'Zainichi' experience. The Japan Times, 9 September. Available at: <http://www.japantimes.co.jp/community/2008/09/09/issues/tacklingthe-zainichi-experience/ $>$ [Accessed 21 August, 2014].

Johnston, E., 2000. Isomura 'sangokujin' explanation irks Koreans. The Japan Times, 30 April. Available at: <http://www.japantimes.co.jp/2000/04/30/announcements/ isomura-sangokujin-explanation-irks-koreans/> [Accessed 21 August, 2014].

Johnston, E., 2001. Ethnic Koreans get home spin on history. The Japan Times, 5 June. Available at: <http://www.japantimes.co.jp/news/2001/06/05/national/ ethnic-koreans-get-home-spin-on-history/> [Accessed 21 August, 2014].

Johnston, E., 2013. Politicians silent on curbing hate speech. The Japan Times, 10 July. Available at: < http://www.japantimes.co.jp/news/2013/07/10/national/ social-issues/politicians-silent-on-curbing-hate-speech/> [Accessed 21 August, 2014].

Kimura, K. 2013. Targeting ethnic high schools. The Japan Times, 11 April. Available at: <http://www.japantimes.co.jp/opinion/2013/04/11/reader-mail/targeting-ethnichigh-schools/ $>$ [Accessed 21 August, 2014]. 
Kingston, J., 2013. Abe ought to show a red card to hate speech now. The Japan Times, 19 October. Available at: <http://www.japantimes.co.jp/opinion/2013/10/19/ commentary/abe-ought-to-show-a-red-card-to-hate-speech-now/> [Accessed 21 August, 2014].

Matsumoto, Y., 2013. Korean singer soothes strained ties. The Japan Times, 18 May. Available at: <http://www.japantimes.co.jp/culture/2007/05/18/culture/ unafraid-of-rightist-rage/ $>$ [Accessed 21 August, 2014].

Mcbride, B., 2008. Young 'Zainichi' Koreans look beyond Chongryon ideology. The Japan Times, 16 December. Available at: <http://www.japantimes.co.jp/ community/2008/12/16/issues/young-zainichi-koreans-look-beyond-chongryonideology $/>$ [Accessed 21 August, 2014].

Mie, A., 2013. Xenophobia finds fertile soil in web anonymity. The Japan Times, 8 January. Available at: <http://www.japantimes.co.jp/news/2013/01/08/ reference/xenophobia-finds-fertile-soil-in-web-anonymity/> [Accessed 21 August, 2014].

Osaki, T., 2013. Nationalism rearing ugly head with greater frequency. The Japan Times, 23 May. Available at: <http://www.japantimes.co.jp/news/2013/05/23/ national/nationalism-rearing-ugly-head-with-greater-frequency/> [Accessed 21 August, 2014].

Osaki, T., 2014. Kobe neighborhood gets spicy with 'kimchi town' moniker. The Japan Times, 8 January. Available at: <http://www.japantimes.co.jp/news/2014/01/08/ national/kobe-neighborhood-gets-spicy-with-kimchi-town-moniker/> [Accessed 21 August, 2014].

Osumi, M., 2014. Counseling offered for Korean youths in Japan victimized by discrimination. The Japan Times, 22 July. Available at: $<$ http://www.japantimes. co.jp/news/2014/07/22/national/social-issues/counseling-offered-korean-youthsjapan-victimized-discrimination/\#.U_XuOMV_tAo $>$ [Accessed 21 August, 2014].

Sato, D., 2013. Rallies dent business in Koreatown. The Japan Times, 4 August. Available at: <http://www.japantimes.co.jp/news/2013/08/04/national/ralliesdent-business-in-koreatown $>$ [Accessed 21 August, 2014].

Schilling, M., 2007. Unafraid of rightist rage. The Japan Times, 18 May. Available at: $<$ http://www.japantimes.co.jp/culture/2007/05/18/culture/unafraid-of-rightistrage/ $>$ [Accessed 21 August, 2014].

Shimizu, K., 2007. Pachinko seeks to shed shady image as market shrinks. The Japan Times, 25 September. Available at: <http://www.japantimes.co.jp/news/2007/09/25/ reference/pachinko-seeks-to-shed-shady-image-as-market-shrinks/> [Accessed 21 August, 2014].

Statistics Japan, 2010. South and North Korean residents in Japan. Statistics Japan report, September 10, 2010. Available at: <http://stats-japan.com/t/kiji/11618> [Accessed 21 August, 2014].

Takahara, K., 2005. Koreans here inclined to assimilate to dodge racism. The Japan Times, 6 August. Available at: <http://www.japantimes.co.jp/news/2005/08/06/ 
national/koreans-here-inclined-to-assimilate-to-dodge-racism/> [Accessed 21 August, 2014].

The Japan Times, 2000. Osaka recalls booklet over offensive cartoon. The Japan Times, 17 November. Available at: <http://www.japantimes.co.jp/news/2000/11/17/ national/osaka-recalls-booklet-over-offensive-cartoon/> [Accessed 21 August, 2014].

The Japan Times, 2003. North Korea escapees form help group. The Japan Times, 6 February. Available at: <http://www.japantimes.co.jp/news/2003/02/06/national/ north-korea-escapees-form-help-group/> [Accessed 21 August, 2014].

The Japan Times, 2005. Movie portrays struggle of ethnic Korean who became Rikidozan. The Japan Times, 1 January. Available at: <http://www.japantimes. co.jp/news/2005/01/01/national/movie-portrays-struggle-of-ethnic-korean-whobecame-rikidozan/> [Accessed 21 August, 2014].

The Japan Times, 2007. Facing eviction, Uji ghetto gets Seoul aid. The Japan Times, 18 October. Available at: <http://www.japantimes.co.jp/news/2007/10/18/national/ facing-eviction-uji-ghetto-gets-seoul-aid $>$ [Accessed 21 August, 2014].

The Japan Times, 2010a. Koreans, Japanese demand full compensation. The Japan Times, 23 August. Available at: <http://www.japantimes.co.jp/news/2010/08/23/ national/koreans-japanese-demand-full-compensation/> [Accessed 21 August, 2014].

The Japan Times, 2010b. Yearning for multiculturalism. The Japan Times, 10 December. Available at: $<$ http://www.japantimes.co.jp/news/2010/12/10/national/yearningfor-multiculturalism/> [Accessed 21 August, 2014].

The Japan Times, 2010c. Set politics aside: Korean schools. The Japan Times, 4 March. Available at: <http://www.japantimes.co.jp/news/2010/03/04/news/setpolitics-aside-korean-schools/> [Accessed 21 August, 2014].

The Japan Times, 2010d. The annexation of Korea. The Japan Times, 29 August. Available at: $<$ http://www.japantimes.co.jp/opinion/2010/08/29/editorials/theannexation-of-korea/> [Accessed 21 August 2014].

The Japan Times, 2013a. Pro-North students sue over tuition aid. The Japan Times, 20 December. Available at: <http://www.japantimes.co.jp/news/2013/12/20/national/ pro-north-students-sue-over-tuition-aid/> [Accessed 21 August, 2014].

The Japan Times, 2013b. Court bans rightists' hate speech, rallies. The Japan Times, 7 October. Available at: <http://www.japantimes.co.jp/news/2013/10/07/national/ court-bans-rightists-hate-speech-rallies/> [Accessed 21 August, 2014].

The Japan Times, 2013c. Man held during anti-Korean rally. The Japan Times, 22 May. Available at: <http://www.japantimes.co.jp/news/2013/05/22/national/ man-held-during-anti-korean-rally/> [Accessed 21 August, 2014].

The Japan Times, 2013d. Abe and his ministers give anti-foreigner rallies tacit green light. The Japan Times, 19 August. Available at: < http://www.japantimes. co.jp/community/2013/08/19/voices/abe-and-his-ministers-give-anti-foreignerrallies-tacit-green-light/> [Accessed 21 August, 2014].

The Japan Times, 2013e. Tokyo-Seoul ties toxic as Biden visits to push reconciliation. 
The Japan Times, 2 December. Available at: <http://www.japantimes.co.jp/ news/2013/12/02/national/tokyo-seoul-ties-toxic-as-biden-visits-to-pushreconciliation/ $>$ [Accessed 21 August, 2014].

The Japan Times, 2013f. No place for hate speech. The Japan Times, 5 June. Available at: <http://www.japantimes.co.jp/opinion/2013/06/05/editorials/noplace-for-hate-speech/> [Accessed 21 August, 2014].

The Japan Times, 2014a. U.S. human rights report cites anti-Korean hate speech in Japan. The Japan Times, 28 February. Available at: <http://www.japantimes. co.jp/news/2014/02/28/national/u-s-human-rights-report-cites-anti-korean-hatespeech-in-japan/> [Accessed 21 August, 2014].

The Japan Times, 2014b. Japanese high court upholds ruling against anti-Korean activists' hate speech. The Japan Times, 8 July. Available at: <http://www.japantimes. co.jp/news/2014/07/08/national/crime-legal/japanese-high-court-upholds-rulinganti-korean-activists-hate-speech/> [Accessed 21 August, 2014].

The Japan Times, 2014c. Pro-Korean activists held in assault on right-winger. The Japan Times, 16 July. Available at: <http://www.japantimes.co.jp/news/2014/07/16/ national/social-issues/activists-held-assault-right-winger/> [Accessed 21 August, 2014].

The Japan Times, 2014d. Group says Gunma government trying to remove memorial for Korean forced laborers. The Japan Times, 15 July. Available at: $<$ http://www. japantimes.co.jp/news/2014/07/15/national/group-says-gunma-government-tryingremove-memorial-korean-forced-laborers/> [Accessed 21 August, 2014].

The World Factbook, 2015. Central Intelligence Agency. Available at: $<$ https://www. cia.gov/library/publications/the-world-factbook/geos/ja.html> [Accessed 2015 February 2].

United Nations, 1971. International convention on the elimination of all form of racial discrimination. In: Treaties and international agreements registered or filed and recorded with the secretariat of the United Nations. Vol. 660. New York: United Nations, pp. 195-319.

Williams, J., 2007a. Seeing from the Korean side. The Japan Times, 22 May. Available at: $<$ http://www.japantimes.co.jp/community/2007/05/22/issues/seeing-from-thekorean-side/ $>$ [Accessed 21 August, 2014].

Williams, J., 2007b. Koreans speak out on schooling. The Japan Times, 24 July. Available at: <http://www.japantimes.co.jp/community/2007/07/24/issues/ koreans-speak-out-on-schooling/> [Accessed 21 August, 2014].

\section{Endnotes}

1 Sub-title seen while browsing internet

2 http://www.japantimes.co.jp/about-us/

3 This paper was written in August 21, 2014 


\section{About Author}

\section{Arvydas KUMPIS}

$\mathrm{He}$ is a $\mathrm{PhD}$ candidate in the field of Political Sciences at Klaipeda University. He is currently working at Vytautas Magnus University, Centre for Asian Studies as an assistant lecturer and senior coordinator, responsible for relations with Japan. His main scientific interests are associated to Japan's social order, Japanese nationalism, Japan-South Korea relations, Japanese modern history. Latest publication was "Historiography of Zainichi Koreans: review of topics and trends", published in IJAS, no. 9:1, 2014.

a.kumpis@pmdf.vdu.lt 